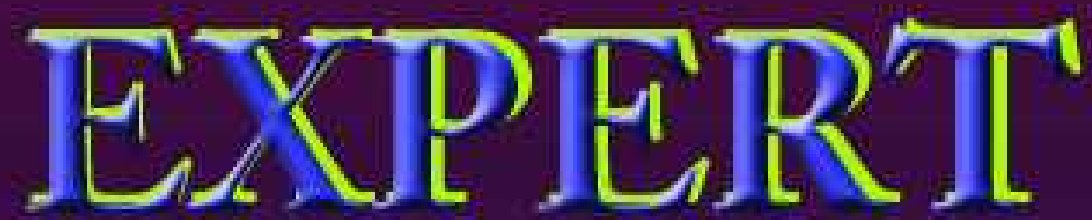

Jurnal Sistem Informasi

PENGEMBANGAN SISTEM APLIKASI LOKASI RUMAH KOST KABUPATEN PRINGSEWU BERBASIS WEB MOBILE

Elisabet Yunaeti Anggareni, Elieser Rudi HCN, Mad Muhaidi

KONSULTASI AKADEMIK BERBASIS ONLINE PROCESSING

Fenty Ariani, Robby Yuli Endra

PERENCANAAN ARSITEKTUR SISTEM INFORMASI MENGGUNAKAN MODEL ENTERPRISE ARCHITECTURE PLANNING (EAP)

di DIREKTORAT RESERSE KRIMINAL UMUM POLDA LAMPUNG

Hilda Dwi Yunita

DECISION SUPPORT SYSTEMMENGGUNAKAN METODE SAW DALAM MENENTUKAN KINERJA APARATUR PEMERINTAH KECAMATAN

M. Islam Mahdi, Rinawati, Tri Susilowati, Zul Kirom

PEMILIHAN CAFE TERBAIK MENGGUNAKAN METODE ANALYTICAL HIERARCHY PROCESS ( AHP)

Sti Ipnuwati, Khusnul Khotimah, Keni Puspita Sari

PEMETAAN COBIT 4.1 UNTUK PENILAIAN KEMATANGAN TATA KELOLA TI Yuthsi Aprilinda, Ayu Kartika Puspa

ISSN : 2088-5555 


\section{Expert}

Jurnal Manajemen Sistem Informasi dan Teknologi

Volume 08, Nomor 01, Juni 2018

\begin{tabular}{|l|l|}
\hline Judul & Hal \\
\hline $\begin{array}{l}\text { PENGEMBANGAN SISTEM APLIKASI LOKASI RUMAH } \\
\text { KOST KABUPATEN PRINGSEWU BERBASIS WEB MOBILE }\end{array}$ & $1-4$ \\
\hline $\begin{array}{l}\text { KONSULTASI AKADEMIK BERBASIS ONLINE } \\
\text { PROCESSING }\end{array}$ & $5-13$ \\
\hline $\begin{array}{l}\text { PERENCANAAN ARSITEKTUR SISTEM INFORMASI } \\
\text { MENGGUNAKAN MODEL ENTERPRISE ARCHITECTURE } \\
\text { PLANNING (EAP) di DIREKTORAT RESERSE KRIMINAL }\end{array}$ & $13-21$ \\
UMUM POLDA LAMPUNG & \\
\hline $\begin{array}{l}\text { DECISION SUPPORT SYSTEMMENGGUNAKAN METODE } \\
\text { SAW DALAM MENENTUKAN KINERJA APARATUR }\end{array}$ & $22-28$ \\
PEMERINTAH KECAMATAN & $29-38$ \\
\hline $\begin{array}{l}\text { PEMILIHAN CAFE TERBAIK MENGGUNAKAN METODE } \\
\text { ANALYTICAL HIERARCHY PROCESS AHP) }\end{array}$ & $39-48$ \\
\hline $\begin{array}{l}\text { PEMETAAN COBIT 4.1 UNTUK PENILAIAN } \\
\text { KEMATANGAN TATA KELOLA TI }\end{array}$ & \\
\hline
\end{tabular}

Fakultas Ilmu Komputer

Universitas Bandar Lampung

\begin{tabular}{|l|l|l|l|l|}
\hline JMSIT & Volume 08 & Nomor 01 & Lampung, Juni 2018 & ISSN 2088-5555 \\
\hline
\end{tabular}




\section{TIM PENYUNTING}

\section{Penanggung Jawab}

Ahmad Cucus, S.Kom., M.Kom.

Ketua Tim Redaksi:

Taqwan Thamrin, ST, M.Sc.

Penyunting Ahli (Mitra Bestari):

Mustofa Usman, Ph.D (Universitas Lampung)

Dra. Wamiliana, MA., Ph.D (Universitas Lampung)

Iing Lukman, M.Sc., Ph. D (Universitas Malahayati)

\section{Penyunting:}

Handri Santoso, M.Eng., Dr. Eng

Fenty Ariani, S.Kom, M.Kom

Robby Yuli Endra, S.Kom.,M.Kom

Ayu Kartika Puspa, S.Kom, M.TI

Erlangga, S.Kom, M.Kom

Pelaksana Teknis:

Wingky Kusuma, S.Kom

\section{Alamat Penerbit/Redaksi:}

Pusat Studi Teknologi Informasi

Fakultas Ilmu Komputer

Universitas Bandar Lampung

Gedung M Lt.2

Jl. ZA Pagar Alam No.89, Gedong Meneng, Rajabasa

Bandar Lampung

Email: jurnalfik@ubl.ac.id 


\title{
PEMILIHAN CAFE TERBAIK MENGGUNAKAN METODE ANALYTICAL HIERARCHY PROCESS (AHP)
}

\author{
Sri Ipnuwati ${ }^{\# 1}$, Khusnul Khotimah ${ }^{* 2}$, Keni Puspita Sari ${ }^{\# 3}$ \\ Program Studi Manajemen Informatika STMIK Prngsewu \\ Jl. Wisma Rini No. 09 pringsewu Lampung \\ Telp.(0729) 22240, Website www.Stmikpringsewu.ac.id \\ ${ }^{1}$ khusnulnanu97@gmail.com \\ ${ }^{2}$ nengachiedgmail.com \\ ${ }^{3}$ keypuspita13@gmail. com
}

\begin{abstract}
Abstrak
Bisnis Cafe di tanah Air terus tumbuh pesat sehingga patut diperhitungkan sebagai salah satu bisnis yang menguntungkan di era modern ini. Pemilihan Cafe terbaik dibutuhkan beberapa kriteria yang cocok dengan selera konsumen. Salah satu cafe yang diharapkan oleh konsumen adalah Cafe yang dapat dinikmati oleh semua kalangan usia mulai dari orang tua, dewasa, remaja bahkan anak-anak sekalipun, sehingga masyarakat yang ingin pergi ke Cafe bersama keluarga bisa saling mendapatkan kenyamanan dalam satu tempat yang sama. Penelitian ini mengembangkan Sistem Pendukung Keputusan (SPK) dengan memanfaatkan metode Analytical Hierarchy Process (AHP) sebagai proses dalam pemilihan Cafe terbaik. Untuk menentukan Cafe terbaik, cafe harus memenuhi kriteria-kriteria yang telah ditentukan, yaitu rasa, harga, suasana, pelayanan, fasilitas dan kebersihan. Peneliti melakukan wawancara kepada para pengunjung Cafe, melakukan pengamatan secara langsung di Cafe yang diteliti dan memanfaatkan teori yang ada yang menyangkut ilmu-ilmu sistem informasi dan teknologi informasi. Dari hasil pengujian tersebut rengking dan bobot dari Cafe 3 atau P3 mendapatkan nilai tertinggi yaitu 0,31 bobot kategori penilaian dengan nilai bobot yang sudah ditentukan.
\end{abstract}

Kata Kunci : SPK, Analytical Hierarchy Process (AHP), Cafe.

\section{PENDAHULUAN}

Saat ini lebih dari 10.000 Cafe di Indonesia yang diprediksi masih akan terus tumbuh. General Manager Reed Panorama Exhibitions, James Boy mengatakan, Indonesia merupakan pasar besar untuk bisnis Cafe. Sebab kelas menengah tanah air terus tumbuh dan Indonesia mempunyai penduduk yang sangat banyak. Sehingga bisnis Cafe di tanah air akan terus tumbuh pesat dan patut diperhitungkan sebagai salah satu bisnis yang menguntungkan di era modern ini.

Masyarakat memiliki kriteria masing-masing dalam memilih Cafe yang akan dipilih untuk menghilangkan rasa jenuh atau hanya sekedar menghabiskan waktu bersama keluarga. Salah satu cafe yang diharapkan oleh masyarakat adalah Cafe yang dapat dinikmati oleh semua kalangan usia mulai dari orang tua, dewasa, remaja bahkan anak-anak sekalipun. Sehingga masyarakat yang ingin pergi ke Cafe bersama keluarga bisa saling mendapatkan kenyamanan dalam satu tempat yang sama.

Salah satu metode yang digunakan untuk sistem pendukung keputusan adalah metode
AHP (Analytical Hierarchy Process). Metode AHP merupakan salah satu metode pengambilan keputusan multi kriteria berdasarkan pada konsep outranking dengan menggunakan perbandingan berpasangan dari alternatif-alternatif berdasarkan setiap kriteria yang sesuai. Metode ini digunakan karena mampu menyelesaikan rekomendasi dari kasus multi kriteria dalam penentuan Cafe terbaik.

Menurut penelitian yang dilakukan (Meri, 2017) dalam "Sistem Pendukung Keputusan Menentukan Keluarga Miskin Menggunakan Metode Analitical Hierarchy Proses (Studi Kasus Pekon Waymanak Kabupaten Tanggamus)". Program bantuan keluarga miskin adalah kompensasi yang diberikan pemerintah kepada orang miskin guna mengurangi beban ekonomi yang semakin menekan kehidupan mereka, dalam penelitian ini dari hasil pengujian rangking dan bobot dari janda tua umur 70-80 tahun, pendapatan perhari >10ribu mendapatkan nilai tertinggi yaitu 3,75 bobot kategori penilaian dengan nilai bobot yang sudah ditentukan, dengan demikian hasil yang diharapkan lebih akurat dan sistem yang dirancang tersusun secara sitematis. (Meri, 2017) 
Penelitian yang dilakukan oleh (Saragih, 2013) dalam "Penerapan Metode Analitycal Hierarchy Process (AHP) pada Sistem Pendukung Keputusan Pemilihan Laptop". Merk Laptop dengan beragam spesifikasi yang dijual dipasaran membuat pengguna menjadi kesulitan dalam menentukan pilihan yang sesuai dengan keinginan dan anggaran mereka. Maka dirancanglah sebuah Sistem Pendukung Keputusan pemilihan laptop dengan menggunakan metode AHP agar pengguna dapat menentukan pilihan laptop dengan tepat sesuai dengan keinginan dan anggarannya. Dalam penelitian ini dilakukan penentuan kriteria dan bobot untuk dihitung secara sistematik, metode AHP yang bisa memecahkan berbagai masalah pengambilan keputusan multikriteria, dapat juga digunakan untuk memecahkan masalah dengan data yang riil dan dilakukan melalui proses penyelesaian sistematika ataupun ilmiah maka system ini akan memberikan suatu informasi dengan tepat dan benar. (Saragih, 2013)

Untuk menentukan Cafe terbaik, cafe harus memenuhi kriteria-kriteria yang telah ditentukan, yaitu Rasa, Harga, Suasana, Pelayanan, Fasilitas dan Kebersihan. Akan tetapi, pihak penentu dalam hal ini yaitu para pengunjung masih merasa kesulitan untuk memilih Cafe terbaik ini. Sehingga diperlukan suatu sistem pengambilan keputusan yang dapat membantu dalam menentukan Cafe mana yang merupakan Cafe terbaik yang dipilih oleh pengunjung atau customer.

\subsection{Identifikasi Masalah}

Dalam uraian diatas, dapat diidentifikasi masalah yang ada, yaitu : Masih banyak custumer atau pengunjung Café yang kurang puas terhadap Cafe yang pernah mereka kunjungi.

\subsection{Ruang Lingkup Masalah}

Adapun ruang lingkup masalah yang dibahas pada penelitian ini adalah :

a. Sistem pendukung keputusan yang dibangun hanya untuk menetukan Cafe terbaik.

b. Sistem pendukung keputusan pemilihan Cafe terbaik dengan menggunakan metode AHP.

c. Studi kasus café yang diteliti adalah café di daerah kabupaten Tanggamus Kecamatan Gisting.

\subsection{Rumusan Masalah}

Dari Latar Belakang diatas, didapatkan rumusan masalah sebagai berikut, Bagaimana cara menentukan Cafe tebaik menggunakan metode AHP ?

\subsection{Tujuan Penelitian}

Tujuan penelitian ini adalah Menentukan Cafe terbaik berdasarkan kriteria serta bobot-bobot yang sudah ditentukan menggunakan metode AHP.

\subsection{Manfaat Penelitian}

Manfaat dari penelitian ini adalah :

a. Membantu para Cafetarian untuk menentukan Cafe terbaik.

b. Membantu pemilik Cafe agar dapat meningkatkan kualitas Cafe yang dimiliki.

\section{LANDASAN TEORI}

\subsection{Sistem Pendukung Keputusan}

Sistem Pendukung Keputusan (SPK) / Decision Support System (DSS) adalah system informasi interaktif yang menyediakan informasi, pemodelan dan pemanipulasian data. Sistem itu digunakan membantu pengambilan keputusan dalam situasi yang semi terstruktur dan situasi yang tidak terstruktur, dimana tak seorangpun tahu secara pasti bagaimana keputusan harusnya dibuat.

Sistem Pendukung Keputusan (SPK) / Decision Support System (DSS) biasanya dibangun untuk mendukung solusi atas suatu masalah atau untuk mengevaluasi suatu peluang. DSS yang seperti itu disebut aplikasi DSS. Aplikasi DSS digunakan dalam pengambilan keputusan , aplikasi DSS menggunakan data, memberikan antarmuka pengguna yang mudah dan dapat menggabungkan pemikiran pengambil keputusan.

DSS lebih ditunjukan untuk mendukung manajemen dalam melakukan pekerjaan yang bersifat analitis dalam situasi yang kurang terstruktur dan dengan kriteria yang kurang jelas. DSS tidak dimaksudkan untuk tidak mengotomatisasikan pengambilan keputusan, tetapi memberikan perangkat interaktif yang memungkinkan pengambil keputusan untuk melakukan berbagai analisis menggunakan model-model yang tersedia. (Kusriani, 2014)

\subsubsection{Kelebihan Sistem Pendukung Keputusan (SPK)}

Kelebihan Sistem Pendukung Keputusan (SPK) yaitu Dapat memperluas kemampuan pengambil keputusan, menghemat waktu yang dibutuhkan untuk memecahkan masalah, menghasilkan solusi dengan lebih cepat, mampu memberikan berbagai alternatif dalam pengambilan keputusan, memperkuat keyakinan pengambil keputusan dan 
memberikan keuntungan kompetitif bagi organisasi secara keseluruhan.

\subsubsection{Kekurangan Sistem Pendukung keputusan (SPK)}

Walaupun dirancang dengan sangat teliti dan mempertimbangkan seluruh faktor yang ada, Sistem pendukung Keputusan (SPK) mempunyai kekurangan atau keterbatasan diantaranya yaitu ada beberapa kemampuan manajemen dan bakat manusia yang tidak dapat dimodelkan, SPK terbatas untuk memberikan alternatif dari pengetahuan yang diberikan, proses-proses yang dapat dilakukan oleh SPK tergantung pada kemampuan perangkat lunak yang digunakan, harus selalu diadakan perubahan secara kontinyu dan SPK dirancang untuk membantu / mendukung pengambilan keputusan dengan mengolah informasi dan data yang diperlukan dan bukan untuk mengambil alih pengambilan keputusan.

\subsection{Analytical Hierarchy Process (AHP)}

Analytical Hierarchy Process (AHP) adalah metode untuk memecahkan suatu situasi yang komplek tidak terstruktur kedalam beberapa komponen dalam susunan yang hirarki, dengan memberi nilai subjektif tentang pentingnya setiap variabel mana yang memiliki prioritas paling tinggi guna mempengaruhi hasil pada situasi tersebut. (Mardiati, 2017)

Proses pengambilan keputusan pada dasarnya adalah memilih suatu alternatif yang terbaik. Seperti melakukan penstrukturan persoalan, penentuan alternatif-alternatif, penetapan nilai kemungkinan untuk variabel aleatori, penetap nilai, persyaratan preferensi terhadap waktu dan spesifikasi atas resiko.

Analytical Hierarchy Process (AHP) digunakan sebagai metode pemecahan masalah dibanding dengan metode yang lain karena alasan-alasan sebagai berikut :

a. Struktur yang hirarki, sebagai konsekuensi dari kriteria yang dipilih, sampai pada sub kriteria yang paling dalam.

b. Memperhitungkan validitas sampai dengan batas toleransi inkonsistensi berbagai kriteria dan alternatif yang dipilih oleh pengambilan keputusan.

c. Memperhitungkan daya tahan output analisis sensitivitas pengambilan keputusan

\subsubsection{Kelebihan Metode AHP}

Kelebihan dari model AHP dibandingkan dengan model pengambilan keputusan yang lain terletak pada kemampuannya untuk memecahkan masalah multiobjectives dengan multikriteria. Kebanyakan model yang sudah ada memakai single objectives dengan multikriteria. Model Linear Programming misalnya, memakai suatu tujuan dengan banyak kendala (kriteria). Kelebihan model AHP ini lebih disebabkan oleh fleksibelitasnya yang tinggi terutama dalam pembuatan hirarki. Sifat fleksibel tersebut membuat model AHP dapat menangkap beberapa tujuan dan beberapa kriteria sekaligus dalam sebuah model atau sebuah hirarki.

\subsubsection{Kekurangan Metode AHP}

Disamping kelebihan-kelebihan yang dimilikinya, model AHP juga mempunyai beberapa kelemahan. Ketergantungan model ini terhadap input berupa persepsi seorang ahli akan membuat hasil akhir dari model ini menjadi tidak ada artinya apabila si ahli memberikan penilaian yang keliru. Kebanyakan orang bertanya apakah persepsi dari seorang ahli tersebut dapat mewakili kepentingan orang banyak atau tidak.

Keraguan seperti ini tidak lain disebabkan oleh kenyataan bahwa setiap orang mempunyai persepsi yang berbeda dengan orang lain. Karenanya, untuk model AHP ini dapat diterima oleh masyarakat, perlu diberikan kriteria dan batasan tegas dari seorang ahli serta meyakinkan masyarakat untuk menganggap bahwa persepsi si ahli dapat mewakili pendapat masyarakat atau paling tidak sebagian masyarakat.

\subsection{Café}

Menurut Longman dalam Dictionary of English Language and Culture cafe adalah restoran kecil yang melayani atau menjual makanan ringan dan minuman, cafe biasanya digunakan orang untuk rileks. (Lenterakecil n.d.)

Cafe secara umum ada yang buka dari pagi sampai malam (10.00-22.00) atau buka mulai dari sore sampai dini hari (18.00-02.00). Dengan demikian, yang membedakan cafe dengan restoran atau tempat makan yang lain adalah lebih mengutamakan hiburan dan kenyamanan pengunjung dan hanya menyediakan menu minuman dan makanan ringan.

Cafe biasanya tidak menyediakan menu makanan utama namun hanya menyediakan minuman dan makanan ringan sebagai menu hidangan dan ada juga yang menyediakan live 
music sebagai hiburan bagi para pengunjung yang datang. Makanan dan minuman yang terdapat dalam café umumnya antara lain :

a. Hot Drrink seperti Coffe

b. Cold Drink seperti ice coffe, ice tea, soft drink.

c. Hot Food seperti Sandwich, burger

d. Cold Food seperti Salad, baker dan snack

Dalam pemilihan Cafe terbaik ini, Cafe harus memenuhi kriteria-kriteria yang telah ditentukan yaitu yang pertama rasa makanan atau minuman pada cafe tersebut rasa nya enak dan cocok untuk semua kalangan usia, yang kedua harga makanan atau minuman nya murah, yang ketiga suasana nya nyaman dan dapat menghilangkan kejenuhan, yang keempat pelayanan nya ramah, gesit dan respon yang cepat, yang kelima fasilitas nya lengkap ada wifi, stopkontak listrik, TV, kipas angina atau AC, toilet, tempat parkir, Musholla, Koran, tempat bermain anak dan yang keenam semua fasilitas nya selalu dalam keadaan bersih.

\section{METODE PENELITIAN}

\subsection{Metode Pengumpulan Data}

Metode pengumpulan data yang digunakan adalah sebagai berikut :

a. Wawancara

Dalam teknik ini dilakukan wawancara langsung dengan para pengunjung Cafe terutama di Cafe yang akan di teliti.

b. Observasi

Dalam teknik ini dilakukan pengamatan pada objek secara langsung di Cafe yang akan di teliti.

c. Kepustakaan

Dalam teknik ini dilakukan pemanfaatkan teori-teori yang ada yang menyangkut ilmu-ilmu sistem informasi dan teknologi informasi.

\subsection{Metode Analytical Hierarchy Process (AHP)}

Pemilihan Cafe terbaik ini dibutuhkan beberapa kriteria untuk menentukan sebuah keputusan, yaitu : Rasa, Harga, Suasana, Pelayanan, Fasilitas dan Kebersihan.

Penentuan Kriteria
Input :
C1 : Rasa
C2 : Harga
C3 : Suasana
C4 : Pelayanan
C5 : Fasilitas
C6 : Kebersihan

Proses :

$$
\begin{gathered}
\begin{array}{c}
\text { \{ Matriks Perbandingan Kriteria }\} \\
\mathrm{C} 1 \quad(\mathrm{C} 1 / \mathrm{C} 1),(\mathrm{C} 1 / \mathrm{C} 2), \quad(\mathrm{C} 1 / \mathrm{C} 3), \\
(\mathrm{C} 1 / \mathrm{C} 4),(\mathrm{C} 1 / \mathrm{C} 5),(\mathrm{C} 1 / \mathrm{C} 6) \\
\mathrm{C} 2:(\mathrm{C} 1 / \mathrm{C} 1),(\mathrm{C} 1 / \mathrm{C} 1),(\mathrm{C} 1 / \mathrm{C} 3),(\mathrm{C} 1 / \mathrm{C} 4), \\
(\mathrm{C} 1 / \mathrm{C} 5),(\mathrm{C} 1 / \mathrm{C} 6) \\
\mathrm{C} 3:(\mathrm{C} 1 / \mathrm{C} 1),(\mathrm{C} 1 / \mathrm{C} 2),(\mathrm{C} 1 / \mathrm{C} 1),(\mathrm{C} 1 / \mathrm{C} 4), \\
(\mathrm{C} 1 / \mathrm{C} 5),(\mathrm{C} 1 / \mathrm{C} 6) \\
\mathrm{C} 4:(\mathrm{C} 1 / \mathrm{C} 1),(\mathrm{C} 1 / \mathrm{C} 2),(\mathrm{C} 1 / \mathrm{C} 3),(\mathrm{C} 1 / \mathrm{C} 1), \\
(\mathrm{C} 1 / \mathrm{C} 5),(\mathrm{C} 1 / \mathrm{C} 6) \\
\mathrm{C} 5:(\mathrm{C} 1 / \mathrm{C} 1),(\mathrm{C} 1 / \mathrm{C} 2),(\mathrm{C} 1 / \mathrm{C} 3),(\mathrm{C} 1 / \mathrm{C} 4), \\
(\mathrm{C} 1 / \mathrm{C} 1),(\mathrm{C} 1 / \mathrm{C} 6) \\
\mathrm{C} 6:(\mathrm{C} 1 / \mathrm{C} 1),(\mathrm{C} 1 / \mathrm{C} 2),(\mathrm{C} 1 / \mathrm{C} 3),(\mathrm{C} 1 / \mathrm{C} 4), \\
(\mathrm{C} 1 / \mathrm{C} 5),(\mathrm{C} 1 / \mathrm{C} 1)
\end{array}
\end{gathered}
$$

Output :

$\mathrm{C}:$ Kolom matriks

Algoritma Keputusan
Input :
$\mathrm{N}$ : Jumlah Kriteria
$\mathrm{C}$ : Jumlah Elemen

Dalam menyelesaikan permasalahan dengan AHP ada beberapa prinsip yang harus dipahami (Rais, 2016), diantaranya adalah :

a. Membuat Hirarki

Sistem yang kompleks bisa di pahami dengan memecahnya menjadi elemenelemen pendukung, menyusun elemenelemen secara hirarki dan menggabungkannya atau mensintesisnya.

Tabel 1. Daftar Index Random Consistency

\begin{tabular}{|c|c|}
\hline Ukuran Matriks & Nilai IR \\
\hline 1,2 & 0,00 \\
3 & 0,58 \\
4 & 0,90 \\
5 & 1,12 \\
6 & 1,24 \\
7 & 1,32 \\
8 & 1,41 \\
9 & 1,45 \\
10 & 1,49 \\
11 & 1,51 \\
12 & 1,48 \\
13 & 1,56 \\
14 & 1,57 \\
15 & 1,59 \\
\hline
\end{tabular}

b. Penilaian Kriteria dan Alternatif Nilai dan definisi pendapat kualitatif dari skala perbandingan biasa diukur menggunakan tabel analisis seperti berikut : 
Expert - Jurnal Management Sistem Informasi dan Teknologi

Tabel 2. Penilaian Kriteria dan Alternatif

\begin{tabular}{|c|l|}
\hline $\begin{array}{c}\text { Intensitas } \\
\text { Kepentingan }\end{array}$ & \multicolumn{1}{|c|}{ Keterangan } \\
\hline 1 & $\begin{array}{l}\text { kedua elemen sama } \\
\text { pentingnya }\end{array}$ \\
\hline 3 & $\begin{array}{l}\text { Elemen yang satu sedikit } \\
\text { lebih penting daripada } \\
\text { elemen lainnya }\end{array}$ \\
\hline 5 & $\begin{array}{l}\text { Elemen yang satu lebih } \\
\text { penting dari pada elemen } \\
\text { lainnya }\end{array}$ \\
\hline 7 & $\begin{array}{l}\text { Satu elemen jelas lebih } \\
\text { mutlak penting dari pada } \\
\text { elemen lainnya }\end{array}$ \\
\hline 9 & $\begin{array}{l}\text { satu elemen mutlak } \\
\text { penting dari pada elemen } \\
\text { lainnya }\end{array}$ \\
\hline $2,4,6,8$ & $\begin{array}{l}\text { Nilai-nilai antara dua } \\
\text { nilai pertimbangan yang } \\
\text { berdekatan }\end{array}$ \\
\hline Kebalikan & $\begin{array}{l}\text { Jika aktifitas i mendapat } \\
\text { satu angka dibandingkan } \\
\text { dengan aktifitas j, maka j } \\
\text { memiliki nilai } \\
\text { kebalikannya } \\
\text { dibandingkan dengan i. }\end{array}$ \\
\hline
\end{tabular}

c. Menentukan Prioritas (Synthesis Of Priority)

Untuk setiap kriteria dan alternatif, perlu dilakukan perbandingan berpasangan. Nilai-nilai perbandingan tersebut disesuaikan dengan keputusan yang telah ditentukan untuk menghasilkan bobot dan prioritas bobot. Bobot dan Prioritas Bobot dihitung dengan memanipulasi matriks atau melalui penyelesaian persamaan matematika, dengan rumus :

$$
\mathbf{C I}=(\max -\mathbf{n}) / \mathbf{n}
$$

CI : Consistency Index

Max : Eigen Value

$\mathrm{N}$ : Banyak Elemen

Vi menghitung konsistensi ratio (CR)

Dengan rumus $\mathbf{C R}=\mathbf{C I} / \mathbf{C R}$

$$
\begin{array}{ll}
\mathrm{CR} & : \text { Consistency Ratio } \\
\mathrm{CI} & : \text { Consistency Index } \\
\mathrm{RC} & : \text { Random Consistency }
\end{array}
$$

\subsubsection{Prosedur Pemilihan Cafe Terbaik Menggunakan Metode AHP}

Pada dasarnya, prosedur atau langkah-langkah dalam metode AHP meliputi : a. Menyusun Hirarki dari permasalahan yang dihadapi. Hirarki seperti ditunjukkan gambar 1 berikut ini :

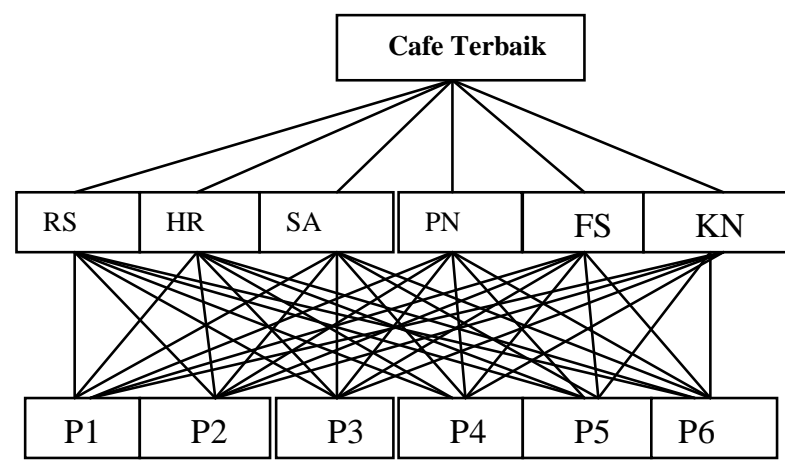

Gambar 1. Hirarki AHP

Keterangan :

Tingkat 1 = Tujuan

Tingkat $2=$ Kriteria

Tingakat $3=$ Alternatif

Pada gambar 1 menunjukkan hirarki seleksi pemilihan cafe terbaik yang berisi alternatif-alternatif yang akan dibandingkan satu sama lain dengan kriterianya. Proses pembandingan nilai tersebut adalah proses pembobotan alternatif untuk mendapatkan prioritas atau rangking dari setiap alternatifnya.

b. Menghitung Nilai Eigen

Menghitung nilai eigen vector dan menguji konsistensinya, jika tidak konsisten maka pengambilan data (preferensi) perlu diulangi. Nilai eigen vector yang dimaksud adalah nilai eigen vector maksimum yang diperoleh.

c. Memeriksa Konsistensi Hirarki Jika nilainya lebih dari $10 \%$, maka penilaian data judgment harus diperbaiki. Namun jika rasio konsistensi (CI/IR) kurang atau sama dengan 0,1 , maka hasil perhitungan bias dinyatakan benar.

\section{PEMBAHASAN}

\subsection{Perhitungan AHP (Analytical Hierarchy Process)}

\subsubsection{Matrik Perbandingan Antar Kriteria} Proses ini dilakukan untuk mengetahui nilai konsistensi rasio perbandingan (CR). Dimana syarat konsistensi harus kecil dari $10 \%$ atau $\mathrm{CR}<0,1$. Sebelum menentukan matrik perbandingan berpasangan antar kriteria, terlebih dahulu ditentukan intensitas 
Expert - Jurnal Management Sistem Informasi dan Teknologi

kepentingan dari masing-masing kriteria. Fungsi menentukan intensitas kepentingan masing-masing kriteria adalah menghindari $\mathrm{CR}>0,1$ atau tidak konsisten.

Perbandingan matrik kriteria berpasangan AHP dapat dilihat pada Tabel 3.

Tabel 3. Matrik Perbandingan Antar Kriteria

\begin{tabular}{|c|c|c|c|c|c|c|}
\hline Kriteria & RS & HR & SA & PN & FS & KN \\
\hline RS & 1 & 3 & $1 / 2$ & $1 / 1$ & 1 & 2 \\
\hline HR & $1 / 3$ & 1 & $1 / 5$ & $1 / 5$ & $1 / 2$ & $1 / 1$ \\
\hline SA & 2 & 5 & 1 & 1 & 3 & 5 \\
\hline PN & 1 & 5 & $1 / 1$ & 1 & 2 & 3 \\
\hline FS & $1 / 1$ & 2 & $1 / 3$ & $1 / 2$ & 1 & 1 \\
\hline KN & $1 / 2$ & 1 & $1 / 5$ & $1 / 3$ & $1 / 1$ & 1 \\
\hline
\end{tabular}

Keterangan :

RS : Rasa

HR : Harga

SA : Suasana

PN : Pelayanan

FS : Fasilitas

$\mathrm{KN}$ : Kebersihan

Setelah diinputkan ke dalam Tabel berpasangan, maka akan dilakukan penjumlahan tiap kolom. Dapat dilihat pada Tabel 4.

Tabel 4. Hasil Penjumlahan Pembobotan Kriteria

\begin{tabular}{|c|c|c|c|c|c|c|}
\hline Kriteria & RS & $\begin{array}{l}\text { H } \\
\mathbf{R}\end{array}$ & SA & PN & $\begin{array}{c}\text { F } \\
\text { S }\end{array}$ & $\begin{array}{c}\text { K } \\
\text { N }\end{array}$ \\
\hline RS & 1 & 3 & $1 / 2$ & $1 / 1$ & 1 & 2 \\
\hline HR & $1 / 3$ & 1 & $1 / 5$ & $1 / 5$ & $1 / 2$ & $1 / 1$ \\
\hline SA & 2 & 5 & 1 & 1 & 3 & 5 \\
\hline PN & 1 & 5 & $1 / 1$ & 1 & 2 & 3 \\
\hline FS & $1 / 1$ & 2 & $1 / 3$ & $1 / 2$ & 1 & 1 \\
\hline KN & $1 / 2$ & 1 & $1 / 5$ & $1 / 3$ & $1 /$ & 1 \\
& & & & & 1 & \\
\hline $\begin{array}{c}\text { JUMLA } \\
\text { H }\end{array}$ & 5,8 & 17 & 3,2 & 4,0 & 8, & 13 \\
\end{tabular}

Setelah dilakukan penjumlahan setiap kolom kriteria pada Tabel 4, selanjutnya membagi tiap kolom dengan jumlah kolom yang telah dijumlahkan. Maka akan diperoleh bobot relatif yang dinormalkan.

Tabel 5. Perhitungan Nilai Eigen

\begin{tabular}{|ll|ll|}
\hline \multicolumn{2}{|c|}{ RS } & \multicolumn{2}{c|}{ HR } \\
\hline $1 / 5,83=0,171$ & $3 / 17$ & $=0,176$ \\
\hline $0,33 / 5,83=0,056$ & $1 / 17$ & $=0,058$ \\
\hline $2 / 5,83$ & $=0,343$ & $5 / 17$ & $=0,3$ \\
\hline $1 / 5,83$ & $=0,171$ & $5 / 17$ & $=0,3$ \\
\hline $1 / 5,83$ & $=0,171$ & $2 / 17$ & $=0,117$ \\
\hline
\end{tabular}

\begin{tabular}{|c|c|c|}
\hline $0,5 / 5,83=0,085$ & $1 / 17$ & $=0,05$ \\
\hline SA & \multicolumn{2}{|c|}{ PN } \\
\hline $0,5 / 3,23=0,154$ & $1 / 4,03$ & $=0,248$ \\
\hline $0,2 / 3,23$ & $0,2 / 4,03$ & $=0,05$ \\
\hline$=0,309$ & $1 / 4,03$ & $=0,248$ \\
\hline $1 / 3,23=0,309$ & $1 / 4,03$ & $=0,248$ \\
\hline $0,33 / 3,23=0,102$ & $0,5 / 4,03$ & $=0,124$ \\
\hline $0,2 / 3,23=0,062$ & $0,33 / 4,03$ & $=0,081$ \\
\hline
\end{tabular}

\begin{tabular}{|ll|ll|}
\hline \multicolumn{2}{|c|}{ FS } & \multicolumn{2}{c|}{ KN } \\
\hline $1 / 8,5$ & $=0,117$ & $2 / 13$ & $=0,153$ \\
\hline $0,5 / 8,5$ & $=0,058$ & $1 / 13$ & $=0,07$ \\
\hline $3 / 8,5$ & $=0,353$ & $5 / 13$ & $=0,384$ \\
\hline $2 / 8,5$ & $=0,235$ & $3 / 13$ & $=0,230$ \\
\hline $1 / 8,5$ & $=0,117$ & $1 / 13$ & $=0,07$ \\
\hline $1 / 8,5$ & $=0,117$ & $1 / 13$ & $=0,07$ \\
\hline
\end{tabular}

Tabel 6. Normalisasi Matrik

\begin{tabular}{|l|c|}
\hline \multicolumn{1}{|c|}{$\begin{array}{c}\text { Normalisasi } \\
\text { Matrik }\end{array}$} & $\begin{array}{c}\text { Nilai } \\
\text { Eigen }\end{array}$ \\
\hline $\begin{array}{l}(0,171+0,176+0,154+0,248+0,117+0,1 \\
53) / 6\end{array}$ & $\mathbf{0 , 1 7}$ \\
\hline $\begin{array}{l}(0,056+0,058+0,062+0,05+0,058+0,07 \\
) / 6\end{array}$ & $\mathbf{0 , 0 5 9}$ \\
\hline $\begin{array}{l}(0,343+0,3+0,309+0,248+0,353+0,384 \\
) / 6\end{array}$ & $\mathbf{0 , 3 2 3}$ \\
\hline $\begin{array}{l}(0,171+0,3+0,309+0,248+0,235+0,230 \\
) / 6\end{array}$ & $\mathbf{0 , 2 4 9}$ \\
\hline $\begin{array}{l}(0,171+0,117+0,102+0,124+0,117+0,0 \\
7) / 6\end{array}$ & $\mathbf{0 , 1 1 7}$ \\
\hline $\begin{array}{l}(0,085+0,05+0,062+0,081+0,117+0.07 \\
) / 6\end{array}$ & $\mathbf{0 , 0 7 8}$ \\
\hline
\end{tabular}

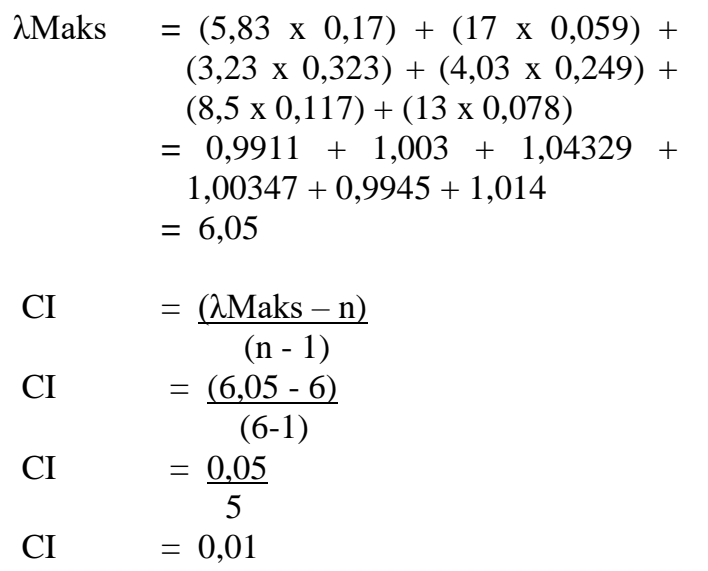

Untuk $\mathrm{n}=6, \mathrm{RI}=1,24($ Lihat Tabel 1$)$

$$
\begin{array}{ll}
\mathrm{CR} & =\frac{(\mathrm{CI})}{(\mathrm{RI})} \\
\mathrm{CR} & =\frac{(0,01)}{(1,24)} \\
\mathrm{CR} & =0.008
\end{array}
$$

Karena $\mathrm{CR}<0.1$ maka perbandingan konsisten 
Expert - Jurnal Management Sistem Informasi dan Teknologi

\section{a. Perbandingan Matrik Cafe Berdasarkan Kriteria Rasa (RS)}

Tabel 7. Nilai Evaluasi Rasa (RS)

\begin{tabular}{|c|c|}
\hline Cafe & Nilai (RS) \\
\hline P1 & 7 \\
\hline P2 & 9 \\
\hline P3 & 10 \\
\hline P4 & 8 \\
\hline P5 & 6 \\
\hline P6 & 5 \\
\hline
\end{tabular}

Berikut matrik perbandingan alternatif dengan kriteria Rasa :

Tabel 8. Matrik Perbandingan Pemilihan Cafe Berdasarkan Kriteria Rasa (RS)

\begin{tabular}{|c|c|c|c|c|c|c|}
\hline Alternatif & P1 & P2 & P3 & P4 & P5 & P6 \\
\hline P1 & 1 & $1 / 2$ & $1 / 3$ & $1 / 1$ & 1 & 2 \\
\hline P2 & 2 & 1 & $1 / 1$ & 1 & 3 & 5 \\
\hline P3 & 3 & 1 & 1 & 2 & 5 & 5 \\
\hline P4 & 1 & $1 / 1$ & $1 / 2$ & 1 & 2 & 3 \\
\hline P5 & $1 / 1$ & $1 / 3$ & $1 / 5$ & $1 / 2$ & 1 & 1 \\
\hline P6 & $1 / 2$ & $1 / 5$ & $1 / 5$ & $1 / 3$ & $1 / 1$ & 1 \\
\hline
\end{tabular}

Langkah selanjutnya adalah penjumlahan setiap kolom. Adapun langkah-langkah untuk menjumlahkan nilai kolom sebagai berikut :

Tabel 9. Penjumlahan Pembobotan Berdasarkan Kriteria Rasa (RS)

\begin{tabular}{|c|c|c|c|c|c|c|}
\hline $\begin{array}{c}\text { Alternat } \\
\text { if }\end{array}$ & $\begin{array}{l}\mathbf{P} \\
\mathbf{1}\end{array}$ & $\begin{array}{l}\mathbf{P} \\
2\end{array}$ & $\begin{array}{l}\mathbf{P} \\
3\end{array}$ & $\begin{array}{l}P \\
4\end{array}$ & $\begin{array}{l}\mathbf{P} \\
5\end{array}$ & $\begin{array}{l}P \\
6\end{array}$ \\
\hline P1 & 1 & $1 / 2$ & $\begin{array}{l}1 / \\
3\end{array}$ & $\begin{array}{l}1 / \\
1\end{array}$ & 1 & 2 \\
\hline P2 & 2 & 1 & $\begin{array}{l}1 / \\
1\end{array}$ & 1 & 3 & 5 \\
\hline P3 & 3 & 1 & 1 & 2 & 5 & 5 \\
\hline P4 & 1 & $\begin{array}{c}1 / \\
1\end{array}$ & $1 / 2$ & 1 & 2 & 3 \\
\hline P5 & $\begin{array}{l}1 / \\
1\end{array}$ & $\begin{array}{l}1 / \\
3\end{array}$ & $\begin{array}{l}1 / \\
5\end{array}$ & $1 / 2$ & 1 & 1 \\
\hline P6 & $\begin{array}{l}1 / \\
2\end{array}$ & $\begin{array}{l}1 / \\
5\end{array}$ & $\begin{array}{l}1 / \\
5\end{array}$ & $\begin{array}{l}1 / \\
3\end{array}$ & $\begin{array}{l}1 / \\
1\end{array}$ & 1 \\
\hline $\begin{array}{c}\text { JUMLA } \\
\text { H }\end{array}$ & $\begin{array}{c}8, \\
5\end{array}$ & $\begin{array}{l}4, \\
03\end{array}$ & $\begin{array}{l}3, \\
23\end{array}$ & $\begin{array}{l}5, \\
83\end{array}$ & 13 & 17 \\
\hline
\end{tabular}

Setelah dilakukan penjumlahan setiap kolom kriteria pada Tabel 9, selanjutnya membagi tiap kolom dengan jumlah kolom yang telah dijumlahkan. Maka akan diperoleh bobot relatif yang dinormalkan.

Tabel 10. Perhitungan Nilai Eigen

$$
\begin{array}{l|l}
\text { P1 } & \text { P2 }
\end{array}
$$

\begin{tabular}{|ll|ll|}
\hline $1 / 8,5$ & $=0,117$ & $0,5 / 4,03$ & $=0,124$ \\
\hline $2 / 8,5$ & $=0,235$ & $1 / 4,03$ & $=0,248$ \\
\hline $3 / 8,5$ & $=0,353$ & $1 / 4,03$ & $=0,248$ \\
\hline $1 / 8,5$ & $=0,117$ & $1 / 4,03$ & $=0,248$ \\
\hline $1 / 8,5$ & $=0,117$ & $0,33 / 4,03$ & $=0,081$ \\
\hline $0,5 / 8,5$ & $=0,058$ & $0,2 / 4,03$ & $=0,05$ \\
\hline
\end{tabular}

\begin{tabular}{|ll|ll|}
\hline \multicolumn{2}{|c|}{ P3 } & \multicolumn{2}{|c|}{ P4 } \\
\hline $0,33 / 3,23=0,102$ & $1 / 5,83$ & $=0,171$ \\
\hline $1 / 3,23=0,309$ & $1 / 5,83$ & $=0,171$ \\
\hline $1 / 3,23=0,309$ & $2 / 5,83$ & $=0,343$ \\
\hline $0,5 / 3,23=0,154$ & $1 / 5,83$ & $=0,171$ \\
\hline $0,2 / 3,23=0,061$ & $0,5 / 5,83=0,154$ \\
\hline $0,2 / 3,23=0,061$ & $0,33 / 5,83=0,056$ \\
\hline
\end{tabular}

\begin{tabular}{|ll|ll|}
\hline \multicolumn{2}{|c|}{ P5 } & \multicolumn{2}{c|}{ P6 } \\
\hline $1 / 13$ & $=0,076$ & $2 / 17$ & $=0,117$ \\
\hline $3 / 13$ & $=0,230$ & $5 / 17$ & $=0,294$ \\
\hline $5 / 13$ & $=0,384$ & $5 / 17$ & $=0,294$ \\
\hline $2 / 13$ & $=0,153$ & $3 / 17$ & $=0,176$ \\
\hline $1 / 13$ & $=0,076$ & $1 / 17$ & $=0,058$ \\
\hline $1 / 13$ & $=0,076$ & $1 / 17$ & $=0,058$ \\
\hline
\end{tabular}

Tabel 11. Normalisasi Matrik

\begin{tabular}{|c|c|}
\hline $\begin{array}{l}\text { Normalisasi } \\
\text { Matrik }\end{array}$ & $\begin{array}{l}\text { Nilai } \\
\text { Eigen }\end{array}$ \\
\hline $\begin{array}{l}(0,117+0,124+0,102+0,171+0,076+0 \\
117) / 6\end{array}$ & $\mathbf{0 , 1 1 7}$ \\
\hline $\begin{array}{l}(0,235+0,248+0,309+0,171+0,230+0 \\
, 294) / 6\end{array}$ & 0,247 \\
\hline $\begin{array}{l}(0,353+0,248+0,309+0,343+0,384+0 \\
, 294) / 6\end{array}$ & $\mathbf{0 , 3 2 1}$ \\
\hline $\begin{array}{l}(0,117+0,248+0,154+0,171+0,153+0 \\
, 176) / 6\end{array}$ & 0,169 \\
\hline $\begin{array}{l}(0,117+0,081+0,061+0,154+0,076+0 \\
, 058) / 6\end{array}$ & 0,091 \\
\hline $\begin{array}{l}(0,058+0,05+0,061+0,056+0,076+0, \\
058) / 6\end{array}$ & 0,059 \\
\hline
\end{tabular}

$$
\begin{aligned}
& \text { גMaks }=(8,5 \times 0,117)+(4,03 \times 0,247)+ \\
& (3,23 \times 0,321)+(5,83 \times 0,169)+ \\
& (13 \times 0,091)+(17 \times 0,059) \\
& =0,9945+0,99541+1,03683+ \\
& 0,98527+1,183+1,003 \\
& =6,19801 \\
& \mathrm{CI}=\underline{(\lambda \text { Maks }-\mathrm{n})} \\
& \text { (n-1) } \\
& \text { CI } \quad=\underline{(6,19801-6)} \\
& (6-1) \\
& \text { CI }=\frac{0,19801}{5} \\
& \text { CI } \quad=0,04
\end{aligned}
$$

Untuk $n=6, R I=1,24($ Lihat Tabel 1$)$

$\mathrm{CR} \quad=\underline{(\mathrm{CI})}$ 
Expert - Jurnal Management Sistem Informasi dan Teknologi

$$
\begin{array}{ll}
\mathrm{CR} & =\frac{(0,04)}{(1,24)} \\
\mathrm{CR} & =0.032
\end{array}
$$

Karena $\mathrm{CR}<0.1$ maka perbandingan konsisten

*Begitu seterusnya (Perbandingan masingmasing antar kriteria)

\subsubsection{Perhitungan Prioritas Global}

\section{a. Perhitungan Nilai Eigen Perbandingan Antar Alternatif}

Nilai pada Tabel matrik hubungan antar kriteria dengan alternatif ini diambil dari nilai eigen masing-masing alternatif.

Tabel 12. Hasil Matrik Vektor Pembobotan Kriteria Normalisasi

\begin{tabular}{|c|c|c|c|c|c|c|}
\hline \multirow{2}{*}{$\begin{array}{c}\text { Altern } \\
\text { atif }\end{array}$} & \multicolumn{7}{|c|}{ Nilai Eigen Alternatif } \\
\cline { 2 - 7 } P1 & RS & HR & SA & PN & FS & KN \\
\hline & 17 & 0,06 & 0,2 & 0,0 & 0,0 & 0,1 \\
& & 40 & 8 & 8 & 69 \\
\hline P2 & 0,2 & 0,11 & 0,1 & 0,1 & 0,3 & 0,0 \\
& 47 & 7 & 17 & 7 & 21 & 78 \\
\hline P3 & 0,3 & 0,32 & 0,3 & 0,3 & 0,2 & 0,3 \\
& 21 & 1 & 21 & 21 & 47 & 22 \\
\hline P4 & 0,1 & 0,17 & 0,0 & 0,1 & 0,0 & 0,1 \\
& 69 & & 8 & 17 & 6 & 16 \\
\hline P5 & 0,0 & 0,20 & 0,0 & 0,2 & 0,1 & 0,0 \\
& 91 & 95 & 6 & 47 & 7 & 58 \\
\hline P6 & 0,0 & 0,08 & 0,1 & 0,0 & 0,1 & 0,2 \\
& 59 & & 7 & 6 & 7 & 47 \\
\hline
\end{tabular}

\section{b. Total Rangking}

Untuk mencari total rangking untuk masingmasing alternatif Cafe terbaik adalah dengan cara mengalikan nilai eigen masing-masing alternatif dengan nilai eigen kriteria, yakni hasil baris tiap nilai eigen dikalikan dengan kolom nilai eigen kriteria. Adapun langkahlangkah nya adalah sebagai berikut :

Perhitungan Total Prioritas Global :

$$
\begin{aligned}
\mathrm{P} 1= & (0,117 \times 0,17)+(0,06 \times 0,059)+(0,240 \times \\
& 0,323)+(0,08 \times 0,249)+(0,08 \times \\
& 0,117)+(0,169 \times 0,078) \\
= & 0,02+0,0354+0,078+0,02+0,00936 \\
& +0,013 \\
= & \mathbf{0 , 1 7 6} \\
\mathrm{P} 2 \quad= & (0,247 \times 0,17)+(0,117 \times 0,059)+ \\
& (0,117 \times 0,323)+(0,17 \times 0,249)+ \\
& (0,321 \times 0,117)+(0,078 \times 0,078)+ \\
= & 0,042+0,007+0,038+0,043+ \\
& 0,038+0,0061 \\
= & \mathbf{0 , 1 7 4 1}
\end{aligned}
$$

$$
\begin{aligned}
\text { P3 } & (0,321 \times 0,17)+(0,321 \times 0,059)+ \\
& (0,321 \times 0,323)+(0,321 \times 0,249)+ \\
& (0,247 \times 0,117)+(0,322 \times 0,078) \\
& =0,054+0,019+0,103+0,08+0,029 \\
& +0,025 \\
& =\mathbf{0 , 3 1}
\end{aligned}
$$

$\mathrm{P} 4=(0,169 \times 0,17)+(0,17 \times 0,059)+$ $(0,08 \times 0,323)+(0,117 \times 0,249)+$ $(0,06 \times 0,117)+(0,116 \times 0,078)$$$
=0,029+0,01+0,026+0,03+0,007
$$$$
+0,009
$$$$
=\mathbf{0 , 1 1 1}
$$

P5 $=(0,091 \times 0,17)+(0,2095 \times 0,059)+$ $(0,06 \times 0,323)+(0,247 \times 0,249)+$ $(0,17 \times 0,117)+(0,058 \times 0,078)$

$=0,015+0,012+0,02+0,061+0,02$ $+0,0045$

$=\mathbf{0 , 1 3 2 5}$

P6 $=(0,059 \times 0,17)+(0,08 \times 0,059)+$ $(0,17 \times 0,323)+(0,06 \times 0,249)+$ $(0,117 \times 0,117)+(0,247 \times 0,078)$

$=0,01+0,004+0,054+0,015+0,013$

$+0,02$

$=\mathbf{0 , 1 1 6}$

Dari hasil perhitungan diatas diketahui bahwa urutan Prioritas Global dari pemilihan Cafe Terbaik yang akan Dipilih konsumen adalah sebagai berikut :

a. Café 1 atau (P1) dengan total nilai 0,175 .

b. Café 2 atau(P2) dengan total nilai 0,1741 .

c. Café 3 atau (P3) dengan total nilai 0 , 31.

d. Café 4 atau (P4) dengan total nilai 0,111 .

e. Café 5 atau (P5) dengan total nilai 0,1325 .

f. Café 6 atau (P6) dengan total nilai 0,116 .

Sehingga yang akan dipilih adalah Cafe 3 atau (P3) dengan nilai $\mathbf{0 , 3 1}$

\subsection{Implementasi Program}

\subsubsection{Tampilan Halaman Utama}

Halaman utama berfungsi untuk menampilkan dan juga mengakses halaman awal dari sebuah program, dapat menampilkan pada topic fitur dan juga merupakan halaman utama dari sebuah program. Berikut adalah tampilan halaman utama : 
Expert - Jurnal Management Sistem Informasi dan Teknologi

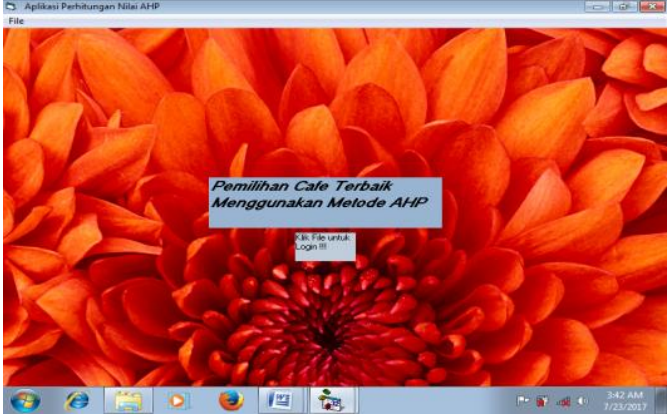

Gambar 2. Tampilan Halaman Utama

\subsubsection{Tampilan Form Login}

Form Login berfungsi sebagai proses autentifikasi bagi user atau pengguna ketika menjalankan suatu program, walaupun pada kenyataannya tidak semua program menggunakan form login. Berikut adalah tampilan form login :

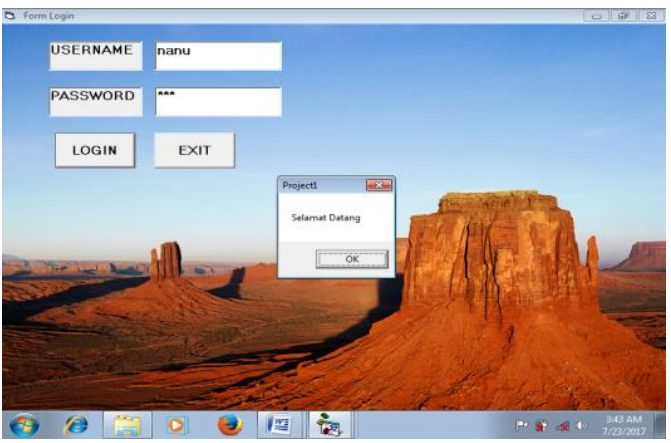

Gambar 3. Tampilan Form Login

\subsubsection{Tampilan Perhitungan Nilai AHP}

Perhitungan nilai AHP berfungsi untuk melakukan pembobotan terhadap semua criteria. Berikut adalah tampilan dari form perhitungan nilai AHP :

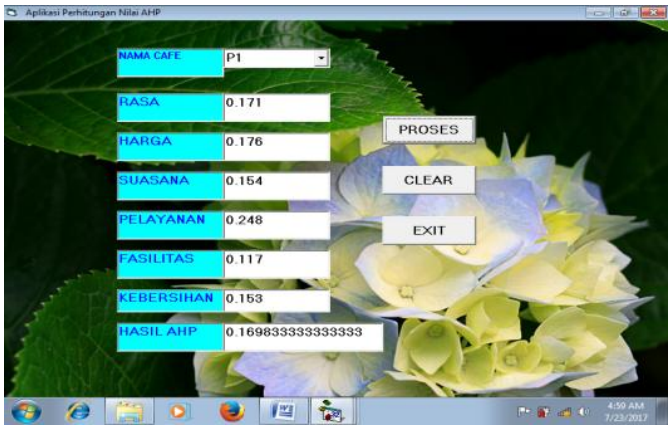

Gambar 4.Tampilan Perhitungan Nilai AHP $\mathrm{P} 1$

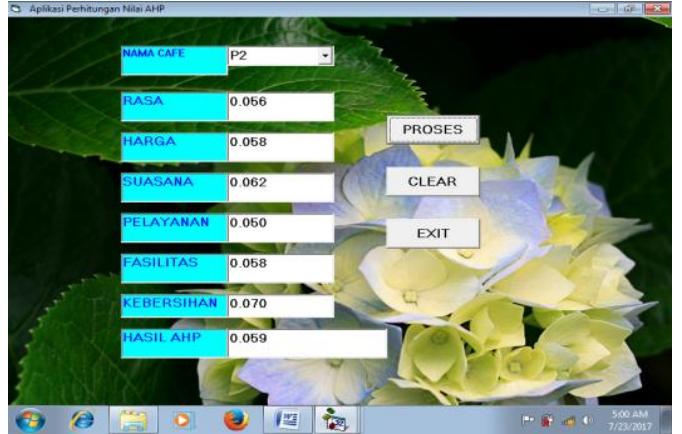

Gambar 5. Tampilan Perhitungan Nilai AHP P2

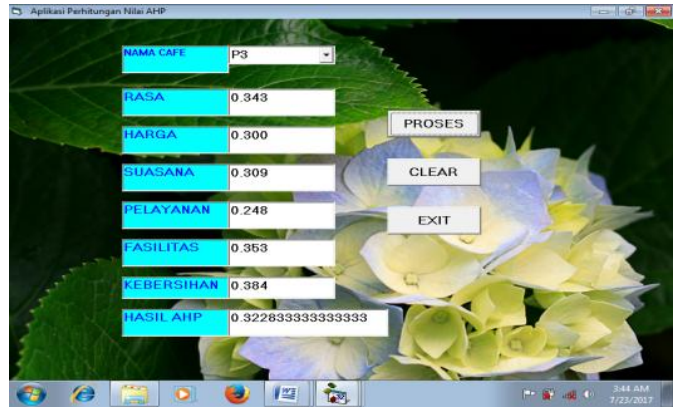

Gambar 6. Tampilan Perhitungan Nilai AHP P3

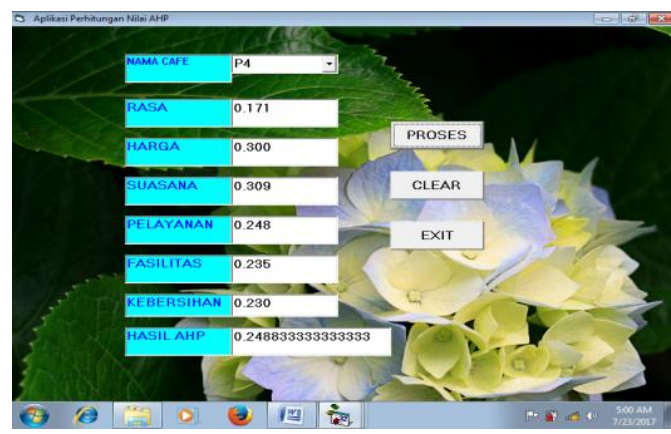

Gambar 7. Tampilan Perhitungan Nilai AHP P4

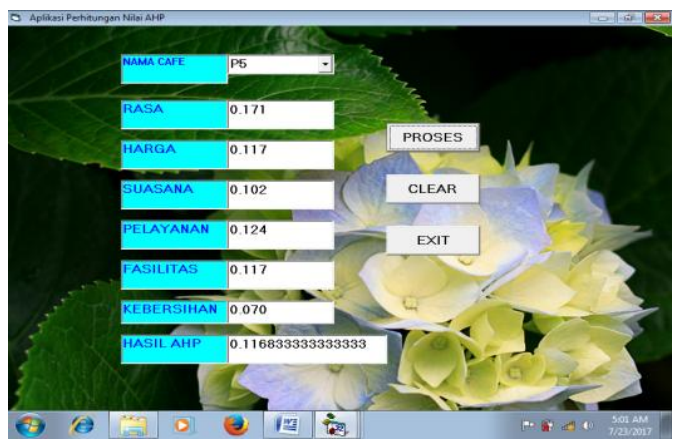

Gambar 8. Tampilan Perhitungan Nilai AHP P5 
Expert - Jurnal Management Sistem Informasi dan Teknologi

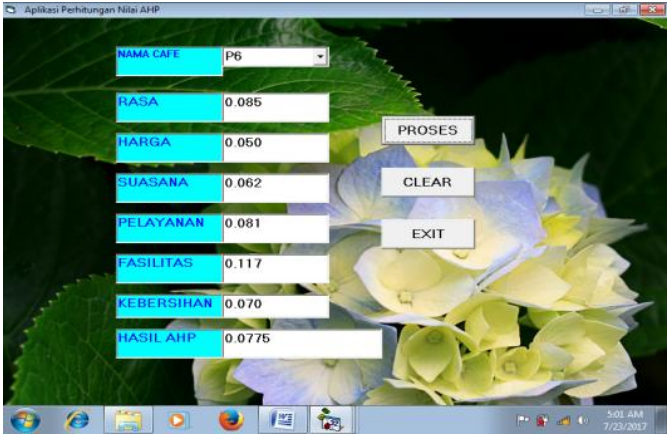

Gambar 9. Tampilan Perhitungan Nilai AHP P6

\section{KESIMPULAN DAN SARAN}

\subsection{Simpulan}

Setelah melakukan pengamatan secara langsung terhadap objek penelitian, maka simpulannya sebagai berikut : Sistem Pendukung Keputusan Pemilihan Cafe terbaik adalah Cafe 3 atau P3 dengan nilai 0,31 karena yang pertama rasa makanan atau minuman pada cafe tersebut rasa nya enak dan cocok untuk semua kalangan usia, yang kedua harga makanan atau minuman nya terjangkau oleh semua kalangan, yang ketiga suasana nya nyaman , dapat menghilangkan kejenuhan dan instagramable, yang keempat pelayanan nya ramah, gesit dan respon cepat, yang kelima fasilitas nya lengkap ada wifi, stopkontak listrik, TV, kipas angin atau AC, toilet, tempat parkir, musholla, Koran, tempat bermain anak dan yang keenam semua fasilitas nya selalu dalam keadaan bersih.

\subsection{Saran}

Beberapa kemungkinan pengembangan penelitian lebih lanjut yang dapat dilakukan yaitu :

a.Untuk melakukan penelitian menggunakan metode TOPSIS, WP dan SAW.

b. Untuk program aplikasi sebaiknya menggunakan program aplikasi lainnya selain proram aplikasi Visual Basic.

\section{DAFTAR PUSTAKA}

[1]. Kusriani. Konsep dan Aplikasi Sistem Pendukung Keputusan. Yogyakarta: Penerbit ANDI, 2014.

[2]. Lenterakecil. apakah kafe itu. https://lenterakecil.com/apakah-kafe-itu/, t.thn.
[3]. Mardiati, Karlina Sri, Oktafianto. "Sistem Pendukung Keputusan (DSS) Penerima Bantuan Rumah Tak Layak Huni (RTLH) Pada Kecamatan Ambarawa Dengan Menggunakan Metode Analytical Hierarchy Proses (AHP)." TAM v=Vol.5 No.1, 2017.

[4]. Meri Anggraini, Suyono. "Sistem Penunjang Keputusan Menentukan Keluarga Miskin Menggunakan Metode Analytical Hierarchy Process (Studi Kasus Pekon Waymanak Kabupaten Tanggamus)." TAM Vol.5 No.1 STMIK PRINGSEWU, 2017.

[5]. Rais, Mhd Sandi. "Sistem Penunjang Keputusan untuk Pemilihan Lokasi Perumahan Menggunakan Analytic Hierarchy Proses." Jurnal Of Computer Science Riau Vol.2 No.2, 2016: 59-72.

[6]. Saragih, Sylvia Hartati. "Penerapan Metode Analitycal Hierarchy Process (AHP) Pada Sistem Pendukung Keputusan Pemilihan Laptop." Pelita Budi Darma vol.4 no.2, 2013. 
Redaksi :

Pusat Studi Teknologi Informasi (PSTI). Gedung Business Center Lt 2 J. Zainal Abidin No. 26 Bandar Lampung Telp. 0721 - 774626 g 772088555000

SistemInformasi@ubl.ac.id 